\title{
Empirical Evidence of Asymmetric Interest Rate Pass-Through in Vietnam
}

\author{
NGUYẼ̃N KHĂC QUỐC BẢO \\ University of Economics HCMC \\ Email: nguyenbao@ueh.edu.vn \\ NGUYẼ̃N HŨ் HUY NHỤ'T \\ University of Economics HCMC \\ Email: nhut@ueh.edu.vn
}

\begin{abstract}
ARTICLE INFO
ABSTRACT

Article history:

This paper seeks evidence and explanatory factors of asymmetric

Received:

May 18, 2013

relationship in interest rate pass-through in Vietnam. The results show that the capital and liquidity requirements of commercial banks are main causes of asymmetric interest rate pass-through in Vietnam. The research based on data from six commercial banks in Vietnam during the period 2009 - 2012 shows that (i) Loan rates from capital Accepted:

July 17, 2013

Sep. 25, 2013

Keywords:

interest rate pass-through, asymmetry, constrained banks are higher than those from unconstrained banks; (ii) Pass-through from monetary policy rate to loan rates is not clear in both constrained and unconstrained banks; and (iii) Loan rates from capital constrained banks are more sensitive to changes in aggregate demand.
\end{abstract} monetary policy 


\section{INTRODUCTION}

Credit channel of monetary policy shows that the act of loosening monetary policy will enhance availability of bank credit through decreasing interest expense. However, it is apparent that during and after the financial crisis of 2007 - 2009, credit growth of commercial banks in Vietnam showed a downward trend while the monetary policy rate was stable at the level of $7 \%$. This raises the question of whether or not the pass-through from interest rates set by monetary policy to loan rates in commercial banks is complete, because if it is complete, implementation of monetary policy through interest rate channel will be effective and vice versa.

By observing the money market in Vietnam, we have approached a new method of researching asymmetric interest rate pass-through which is completely different from traditional ones. It is an application of theoretical model developed by Roelands (2012) to explain adjustments to interest rate by commercial banks under capital and liquidity requirements imposed on banks as a result of changes in interest rates.

In this paper, the research aims to study the aforementioned adjustments by commercial banks under capital and liquidity requirements in a period when monetary policy rate increases and decreases through a dynamic model given by Roelands (2012). The research questions are: (1) is loan rate of capital constrained banks higher than that of unconstrained banks? (2) What is level of pass-through from the policy rates to loan rates between constrained banks and unconstrained banks? And (3) How is the sensitivity of loan rates of both capital constrained and unconstrained banks to fluctuations in the aggregate demand of the economy?

\section{THEORETICAL FRAMEWORK AND LITERATURE REVIEW}

\section{a. Theoretical Background:}

According to Mishkin (1996), monetary policy plays an important role in stabilizing economic growth and controlling inflation, and most central banks have pursued a policy of raising interest rates proactively to prevent an increase in inflation arising from an overheated economy. In order to ensure success for the policy, monetary authorities must evaluate exactly the timing and effect of their policies which requires a full knowledge of pass-through mechanism of the monetary policy.

Mishkin also distinguishes two channels of monetary pass-through. The first one is asset price channel including interest rate channel, exchange rate channel and equity rate channel. The remaining pass-through channel is credit one including bank lending 
channel and the balance-sheet channel. According to Mishkin (2006), the most important channel of monetary pass-through is interest rate channel. Expansionary monetary policy (growth of money supply, for example) causes the real interest rate to decrease through liquidity effect, reduces the capital cost and encourages investments, spending and consumption, thereby increasing the aggregate demand. A decrease in monetary policy rate causes the short-term interest rate to decrease, which makes deposit and loan rates fall. This results in the reduction in opportunity cost of investments and consumption, which increases domestic demands and growth rates along with a higher pressure on inflation.

Additionally, Taylor (1993) gave a rule which was a premise of the subsequent researches on interest rate pass-through, called Taylor rule. This was a reaction function linking changes in nominal interest rate with changes in endogenous variables. With an estimate of a simple model of the FED reaction function, Taylor provided recommendations for how a central bank should set short-term nominal interest rates when the economic conditions change to achieve both its short-run goal for stabilizing the economy and its long-run goal for inflation control.

According to Roelands (2012), banks tend to increase loan rates at roughly the same speed as the policy rates. However, when the policy rates fall, adjustments to loan rates are slower and incomplete. In case of rising (or falling) policy rates, however, capital and liquidity constraints cause the loan rates to increase (or decrease) higher (or lower) than the policy rates.

\section{Figure 1: Interest Rate Pass-Through Mechanism}

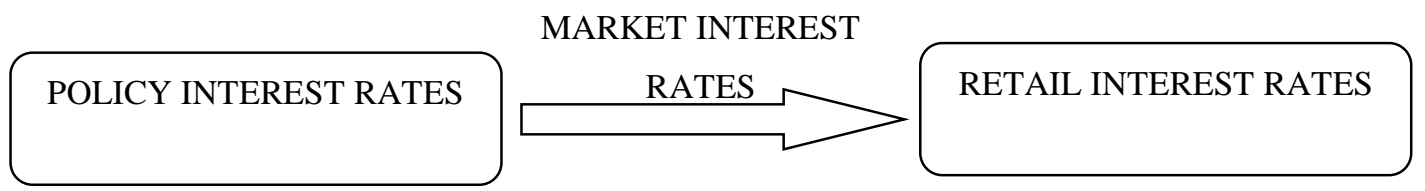

Source: Ming-Hua, Margaritis \& Tourani-Rad (2008)

\section{b. Literature Review:}

Lim (2001), Heffernan (1997 \& 2006), De Bondt (2005), and Blot \& Labondance (2011) measured the efficiency of the short-term interest rate pass-through, the longterm interest rate pass-through, and the asymmetric interest rate pass-through in the interbank market. Lim's research (2001) explores incomplete interest rate pass-through 
between three Australian bank interest rates — bank bond rate, loan rate, and deposit rate -and reaches two conclusions: (1) interest rate adjustments in response to negative and positive shocks are incomplete in the short run, but complete in the long run; and (2) banks adjust their loan and deposit rates at a faster rate during periods of loosening monetary policy than during periods of tight monetary policy.

The research of Cornett et al. (2011) shows how liquidity shocks of banks change during the financial crisis and how they impact on borrowing capacity. Additionally, the research on the role of credit supply in business cycle fluctuations of the Euro area through a DSGE model shows that changes in bank interest rates are slower than changes in policy interest rates (Gerali et al. 2010). The influences of shocks and interest rate pass-through are also studied by Hannan \& Berger (1991); Allen, Carletti \& Gale (2009); and Kumhof et al. (2010).

Analysis of the relationship between banking capitals, lending and macroeconomic operations under the capital requirements (Zicchino Lee, 2006) is a foundation for the research in which Chami \& Cosimano (2010) introduce capital constraints as suggested by Basel II in a typical portrait of monetary policy. These include banks and the mechanism for controlling the money supply through changes in bank reserves. Taking the similar approach, Cosima \& Hakura (2011) examine the impact of the capital requirements based on Basel III framework on bank lending rates. Finally, Roelands (2012) expands the approach developed by Chami \& Cosimano (2010) and shows the role of banks in the asymmetric interest rate pass-through under the capital and liquidity constraints. According to Roelands (2012), more banks are capital constrained during falling rate periods than rising rate periods; constrained banks adjust loan rates at a slower speed than policy rates; and increase loan rates more sharply after their capital adequacy ratios fall in comparison with unconstrained banks.

There are many empirical evidences of interest rate pass-through in Vietnam. Le \& Pfau (2008) analyzed the role of pass-through channels in Vietnam, employing the vector autoregression approach (VAR) and analysis of impulse response function and variance decomposition. Camen (2006) introduced the indirect monetary policy instruments, assuming Vietnam to be a transition economy in the period 1996 -2006. However, research on the role of banks under the capital and liquidity constraint requirements in the asymmetric interest rate pass-through are scarce, almost nonexistent. Thus, this paper seeks empirical evidences in order to determine if the asymmetric 
interest rate pass-through of commercial banks occurs following changes in the policy rate or not.

\section{METHODOLOGY AND DATASET}

\section{a. Dataset:}

Data on typical variables of six commercial banks including Vietinbank, Vietcombank, Sacombank, Eximbank, SHB and ACB are gathered from their audited quarterly financial statements in the period 2009Q1 - 2012Q3. In addition, data on macroeconomic variables such as the real growth rate of GDP, inflation rate and the refinancing rate ${ }^{[1]}$ are gathered from IMF quarterly reports.

However, loan rate is not mentioned in financial statements; thus, according to Roelands (2012), loan rate is measured by a division of total interest income from loans and investment in stocks divided by total assets and securities. Similarly, CAR is collated from annual statements, management reports of banks and authors' calculations in accordance with SBV Circular 13/2010/TT-NHNN dated May 20, 2010 providing "Regulations on prudential ratios in operations of banking institutions".

\section{b. Model:}

Using a dynamic model, Chami \& Cosimano (2010) analyzed the pass-through from the policy rates into loan rates in both capital constrained and unconstrained banks. Roelands (2012), following Chami \& Cosimano (2010), added the liquidity requirement to the model in order to analyze the role of banks in interest rate pass-through. Dynamic model seems to be an appropriate model to measure the level of the pass-through from the policy rates into bank rates under the capital and liquidity constraint requirements. Thus, based on the initial goal and reference models, we decide to use a dynamic banking model presented by Roelands (2012) with data collated from six A-grade banks in Vietnam in order to explore the asymmetric pass-through from the policy rate under the capital constraint requirements.

Roelands, in his 2012 research on the interest rate pass-through under capital and liquidity requirements, made the following predictions: 
Table 1: Theoretical Predictions for the Loan Rate

\begin{tabular}{|c|c|c|c|}
\hline \multirow{2}{*}{ Effect of } & \multirow{2}{*}{ Empirical counterpart } & \multicolumn{2}{|c|}{ Loan Rate $\left(r^{L}\right)$} \\
\hline & & $\begin{array}{c}\text { Capital } \\
\text { unconstrained }\end{array}$ & Capital constrained \\
\hline$\varepsilon^{L} \uparrow$ & $\mathrm{CR} \downarrow$ & $\uparrow$ & $\Uparrow$ \\
\hline$r^{T} \uparrow$ & $\begin{array}{l}\text { Rising refinancing rate } \\
\text { ffr } x \text { (rising rate dummy) }\end{array}$ & $\uparrow$ & 0 \\
\hline$r^{T} \downarrow$ & $\begin{array}{l}\text { Falling refinancing rate } \\
\text { ffr } x \text { (Falling rate dummy) }\end{array}$ & $\Downarrow$ & $\downarrow / 0$ \\
\hline $\mathrm{Y} \uparrow$ & $\begin{array}{c}\text { Detrended real GDP } \uparrow \\
\mathrm{Y}\end{array}$ & $\uparrow / \uparrow$ & $\Uparrow / \Downarrow$ \\
\hline
\end{tabular}

Notes:

$\uparrow, \downarrow$, and 0 indicate a positive, negative, and zero effect, respectively. Moreover, $\Uparrow(\Downarrow)$ relative to $\uparrow$ $(\downarrow)$ indicates a more positive (negative) effect.

Source: Roelands, 2012

Thereby, he developed a model by including the four empirical variables in the equation to determine whether results of the model are compliant with his expectations. Ideally, one would regress the loan rate on the variables as follows:

$$
\begin{gathered}
r_{i t}^{L}=\beta_{0}+\beta_{1}\left(1-c c_{i t}\right) \varepsilon_{i t}^{L}+\beta_{2}\left(c c_{i t}\right) \varepsilon_{i t}^{L}+\beta_{3}\left(1-c c_{i t}\right)\left(\text { fall }_{t}\right) F F R_{t} \\
+\beta_{4}\left(c c_{i t}\right)\left(\text { fall }_{t}\right) F F R_{t}
\end{gathered}
$$

Where the dummy variable $c c_{i t}$ equals 1 when bank $i$ is capital constrained at time $t$ and 0 otherwise; the fall or rise dummy denotes falling or rising rate periods respectively, based on the refinancing rate (FFR); and $\mathrm{Y}$ denotes the aggregate demand derived from the Hodrick-Prescott detrended real GDP. Finally, control variables in the matrix X are bank operating expenses, lags of quarterly loan growth, the lagged ratio of bad debts to 
total assets and its lagged growth rate, lags of quarterly real GDP growth and lags of quarterly inflation.

Since the loan demand shock cannot be observed, the author uses the capital ratio (CR) as the empirical counterpart. However, it is not a perfect empirical measure of the loan demand shock. Therefore, the predicted CR is used as the measure based on the two-stage least squares method, where variable instrument is identified as lag of CR.

The first stage:

$$
C R_{t}=\alpha_{1}+\alpha_{2} C R_{i(t-1)}+\alpha_{3}\left(\text { fall }_{t}\right) F F R_{t}+\alpha_{4}\left(\text { rise }_{t}\right) F F R_{t}+\alpha_{5} Y_{t}+a X_{i t}+v_{i t}
$$

Where $v_{i t}$ is residual. Equation (2) was used for estimating $\widehat{C R}$ and can be used in the second stage regression, such that:

The second stage:

$$
\begin{gathered}
r_{i t}^{L}=\beta_{0}+\beta_{1}\left(1-c c_{i t}\right) \widehat{C R_{l t}}+\beta_{2}\left(c c_{i t}\right) \widehat{C R_{l t}}+\beta_{3}\left(1-c c_{i t}\right)\left(\text { fall }_{t}\right) F F R_{t} \\
+\beta_{4}\left(c c_{i t}\right)\left(\text { fall }_{t}\right) F F R_{t} \\
+\beta_{5}\left(1-c c_{i t}\right)\left(\text { rise }_{t}\right) F F R_{t}+\beta_{6}\left(c c_{i t}\right)\left(\text { rise }_{t}\right) F F R_{t}+\beta_{7}\left(1-c c_{i t}\right) Y_{t}+\beta_{8}\left(c c_{i t}\right) Y_{t}+ \\
b X_{i t}+\mu_{i t}(3)
\end{gathered}
$$

Where $\mu_{i t}$ is residual.

Next, Roelands tested if the loan demand is stable in the period of falling and rising interest rate or not by regressing the loan demand variable according to the following:

$$
\ln \left(L_{i t}^{d}\right)=\delta_{0}-\delta_{1} \widehat{r_{l t}^{L}}+\delta_{2}(\text { rise })_{t} \widehat{r_{l t}^{L}}+\delta_{3}(\text { fall })_{t} \widehat{r_{l t}^{L}}+\delta_{4} Y_{t}+\delta X_{t}^{m}+\vartheta_{i t}
$$

where $X_{t}^{m}$ is a matrix of control variables such as real GDP growth, inflation and a dummy for falling and rising periods and $\vartheta_{i t}$ is the residual.

\section{RESEARCH RESULTS AND DISCUSSION}

Table 2 reports the results of the first-stage regression. The lag of the CR is statistically significant. The refunding rate has a positive relationship with the capital ratio, which is not statistically significant. This contradicts the expectations of the theoretical model .

According to the theoretical model, as interest rates raise, the size of loans falls making the capital ratio to increase; hence the refinancing rate has a positive relationship with the capital ratio. Though our research results are not compliant with expectations of variables in the theoretical model, they show an important implication of the actual 
state interest rate as an instrument in implementation of the monetary policy in Vietnam. It is a lack of connection and rationality between the policy rate (refinancing rate) and the capital ratio.

We surmise that the data do not really reflect bank capital ratio, because banks tend to adjust items in the financial statements in order to meet requirements of capital and liquidity constraints imposed by the SBV. In other words, the unobjective and inaccurate dataset of banks is the reason for deviations of research results.

Additionally, it may be caused by the infancy of capital market in Vietnam where too many administrative instruments are used for implementing economic policies, which makes contradictions between research results and theoretical expectations understandable.

Table 2: Results for the Capital Ratio (2)

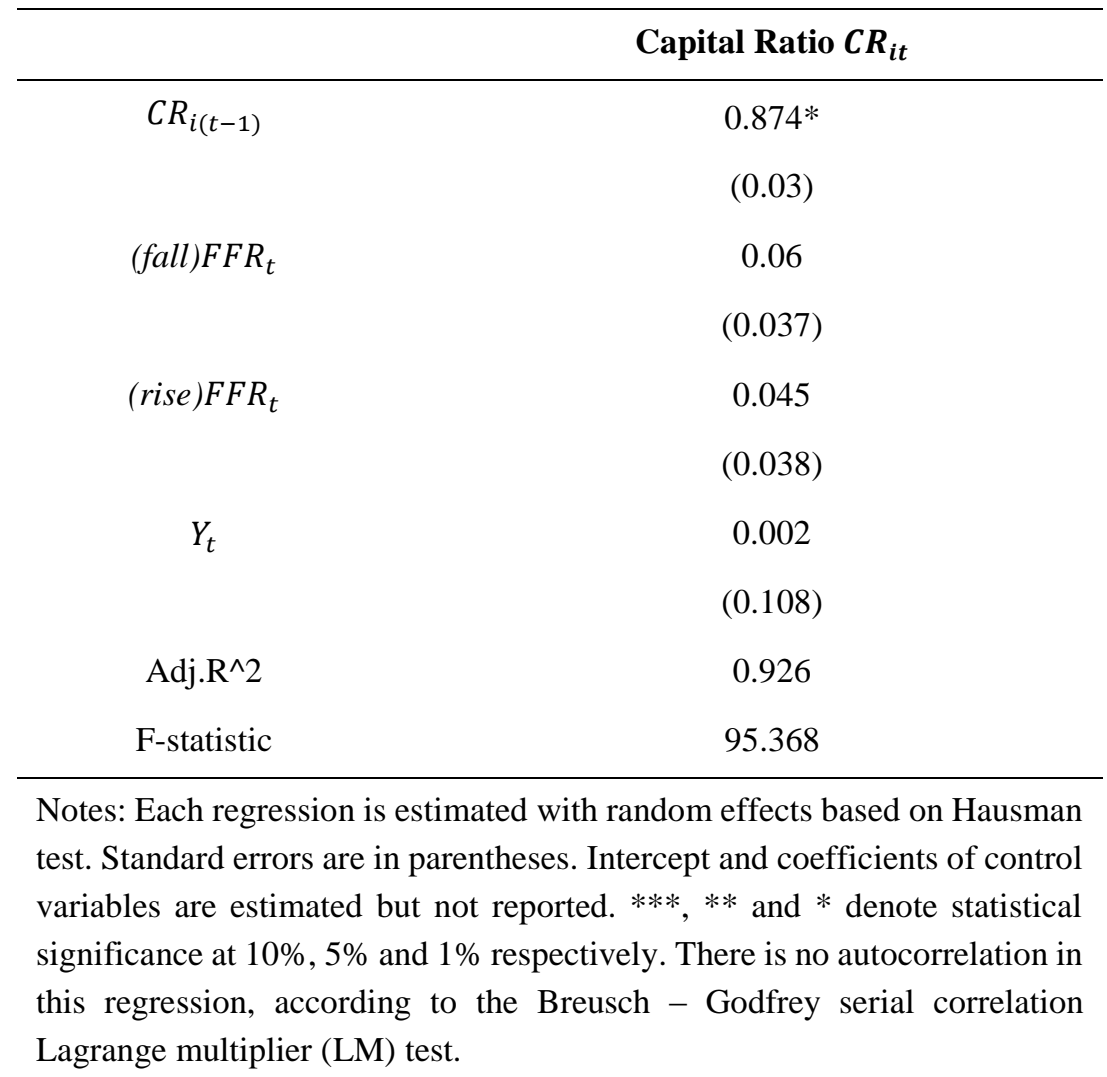

Table 3 indicates the second-stage results for the loan rate. This regression in the table is reported over two columns: the first column shows the results of unconstrained banks, 
and the second column shows the results of constrained banks (when the dummy $\mathrm{cc}_{\text {it }}$ equals 1). In the bottom of this table, "F-statistic" tests whether the estimate coefficients for unconstrained and constrained banks are identical.

Table 3: Results for the Loan Rate (3)

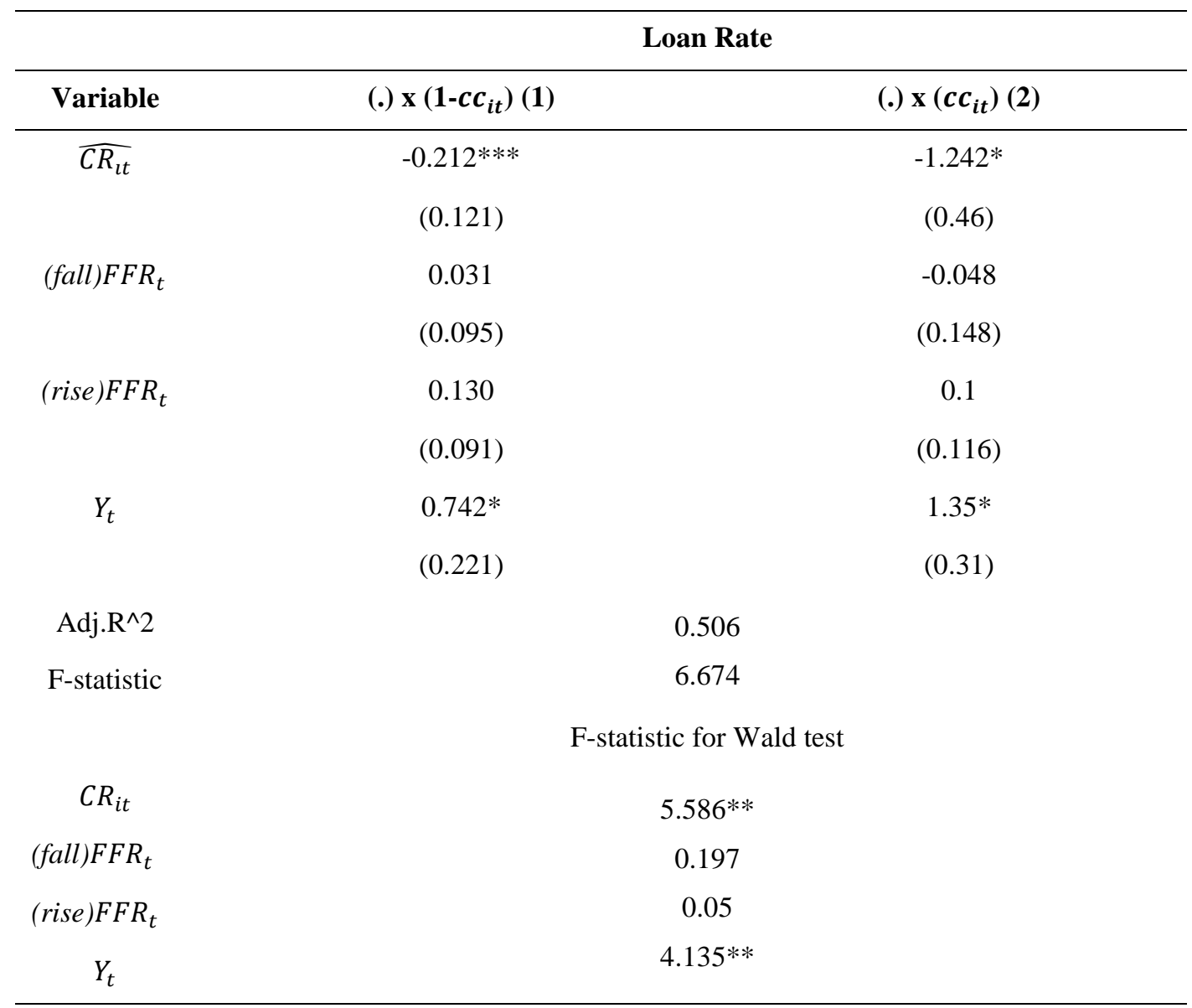

Notes: Each regression is estimated with random effects, based on Hausman test. Standard errors are in parentheses. Intercept and coefficients of control variables are estimated but not reported. $* * *, * *$ and $*$ denote statistical significance at $10 \%, 5 \%$ and $1 \%$ respectively. Two column (1) and (2) present results for capital constrained banks and capital unconstrained banks respectively.

Firstly, CR has a negative sign, contrary to loan rate and a statistical significance at $1 \%$. This means that a drop of $1 \%$ in the capital ratio causes a $0.2 \%$ and $1.2 \%$ increase in the loan rate among capital unconstrained banks and capital constrained banks 
respectively. To meet capital requirements, therefore, the banks, especially the capital constrained ones, should raise interest rate to increase the capital adequacy ratio.

Secondly, regarding the pass-through, changes in the refinancing rate have a positive impact on the loan rate, implying that a fall (or rise) in the refinancing rate results in a fall (or rise) in the loan rate. However, we cannot conclude what the degree is, because the coefficient denoting the degree of pass-through has no statistical significance. Examining this phenomenon more closely, we realize that the refinancing rate does not really influence the loan rate (and rediscount rate as well) in Vietnam. In fact, banks tend to raise the loan rate immediately when the refinancing rate rises, but in reverse, when the refinancing rate falls they are very slow to adjust the loan rate in spite of the SBV orders to lower interest rates.

We suggest two conditions to explain the lack of connection between the policy rate and the loan rate. Firstly, banks only act in accordance with their profit motive and do not care about benefits of other sectors (necessary condition). Secondly, the SBV control over interest rate is inadequate because it only uses commands and administrative measures while Vietnam's laws give quite lenient fines. Additionally, there are mutual interests between policy makers and bank owners (sufficient condition). Those two conditions reduce impact of the refinancing rate on the loan rate, which makes passthrough coefficient statistically insignificant.

However, according to Roelands' research (2012) applying to 125 biggest banks in the US, the aforementioned result is statistically significant and compliant with the theoretical model. When the CR falls, the loan rates raise higher in capital constrained banks than in unconstrained ones. During each rising (or falling) rate period, the loan rates in constrained banks usually increase (decrease) lower than those in unconstrained banks. Specifically, a 100-basis-point drop in the policy rate causes a 5- and 6-basispoint reduction in the loan rates in constrained banks and unconstrained banks respectively.

Thirdly, as predicted by the theoretical model, the loan rates in constrained banks are more sensitive than those offered by unconstrained banks when the GDP changes.

Finally, the result of Wald test for hypothesis Ho: $() \times.\left(1-c c_{i t}\right)=() \times.\left(c c_{i t}\right)$ shows whether the coefficients of variables are the same for both constrained banks and unconstrained banks. The coefficients of the capital ratio and real GDP differ over two groups of banks. It means that adjustments to interest rate by both groups of banks are 
the same while the degree of these adjustments are different in response to changes in the capital ratio and aggregate demand.

Table 4: Results for the Loan Demand (4)

\begin{tabular}{|c|c|}
\hline & Loan Demand \\
\hline \multirow[t]{2}{*}{$\widehat{r_{l t}^{L}}$} & $-0.865^{*}$ \\
\hline & $(0.189)$ \\
\hline \multirow[t]{2}{*}{$\left(\right.$ fall $\left._{t}\right) \widehat{r_{l t}^{L}}$} & $0.192 * * *$ \\
\hline & $(0.105)$ \\
\hline \multirow[t]{2}{*}{$\left(\right.$ rise $\left._{t}\right) \widehat{r_{t t}^{L}}$} & $0.226 * *$ \\
\hline & $(0.113)$ \\
\hline \multirow[t]{2}{*}{$Y_{t}$} & $0.458^{* *}$ \\
\hline & $(0.215)$ \\
\hline Adj. $R^{\wedge} 2$ & 0.801 \\
\hline F-statistic & 31.465 \\
\hline \multirow{2}{*}{$\left(\right.$ fall $\left._{t}\right) \widehat{r_{l t}^{L}}=\left(\right.$ rise $\left._{t}\right) \widehat{r_{l t}^{L}}$} & F-statistic for Wald test \\
\hline & 0.221 \\
\hline
\end{tabular}

Notes: Each regression is estimated with fixed effects, based on Hausman test. Standard errors are in parentheses. Intercept and coefficients of control variables are estimated but not reported. ***, $* *$ and $*$ denote statistical significance at $10 \%, 5 \%$ and $1 \%$ respectively.

Table 4 presents the results of the loan demand regression. The interest rate elasticity of loan demand is -0.9 , which indicates that a $1 \%$ increase in the loan rate causes a $0.9 \%$ drop in loan demand. Conducting Wald test for hypothesis $\mathrm{H}_{0}:\left(\right.$ fall $\left._{t}\right) \widehat{r_{l t}^{L}}=\left(\right.$ rise $\left._{t}\right) \widehat{r_{l t}^{L}}$ (with F-value having no statistical significance), we see that the elasticities are equal, or in other words, there is no change in these elasticities during the observed period (falling or rising rate periods). This shows that the incomplete pass-through from the policy rates to the loan rates results in an asymmetry in bank lending.

\section{RECOMMENDATIONS AND SUGGESTIONS FOR THE POLICIES}

In this paper, we demonstrate that capital and liquidity requirements explain the asymmetric interest rate pass-through. There are two reasons for a bank to raise its 
interest rates when it has some difficulties in capital and liquidity: the first is that the volume of loan demand will fall, enabling the bank to reduce the asset size or to move funds into liquid assets. Second, loans will generate a higher return, which allows a higher retained profit and capital. Therefore, we can conclude that capital and liquidity constraint requirements are the main cause for the asymmetric interest rate pass-through in Vietnam. Through these results, we would like to suggest two recommendations:

Firstly, it is about the policy. SBV should apply the Basel II standards and some Basel III criteria to the whole banking system in response to macroeconomic fluctuations and actual situation in Vietnam in order to improve the size and quality of bank equity and banks' ability to deal with risks, especially unusual losses. Bigger capital can help commercial banks survive financial crisis and reduce their dependence on support from the national treasury; banks therefore should retain a part of profit to increase their loss provisions.

Secondly, on aspect of management, SBV should set up and improve its financial supervision in order to increase its operational capacity and decrease some risks for the whole banking system. Especially, SBV and the government need to strengthen market discipline. Concerning commercial banks that face financial difficulty or poor liquidity but keep operating with an unfair competition affecting badly normal operations of the system, instead of reporting to the SBV for support, the SBV should force them to stop receiving deposits. In addition, ownership percentage for foreign investors could be raised to utilize their financial strength and managerial capacity for domestic banks.

The research also shows that the interest rate is an important pass-through channel for the policy rate. Thus, it is necessary for the SBV to reconsider its implementation of interest rate policy for an optimal performance at the macroeconomic level. Since midMay, 2008, the base rate has been employed as a direct instrument to control business rates of commercial banks. Additionally, the SBV has adopted a flexible policy on open market rates, refinancing rates and rediscount rates to adjust the money market rates. The base rate is determined and publicized according to fluctuations in supply-demand relation on capital market, targets of the monetary policy and the other factors on the money market, and international and local foreign exchange markets.

However, because the base rate is only an instrument for intervening directly in business rates of commercial banks, the SBV, in the short term, allowed agreed-upon loan rates and issuance of credit cards and beefed up its mechanism for inspection and 
supervision to restrict risks. In the long term, the SBV may allow interest rate liberalization when macroeconomic conditions are stable, financial and monetary market is transparent and well developed, and inflation rate is controlled; and develop the payment system to control flows of disposable capital of banks, stock market and other financial institutions, thereby improving competitiveness and ability to ensure safety of the system of commercial banks and maintaining budget deficit at a low level.

Furthermore, the research results also reveal a contradiction when monetary policy targets are linked with management of banking system, and this contradiction may adversely affect effectiveness of implementation of the monetary policy. Thus, we see that there are many inadequacies in management of Vietnam's banking system.

The SBV acts as a ministerial tool of the government to control the money supply, banking system and foreign exchange market and as a central bank to issue currency, plays the role of the lender of last resort and provides monetary services for the government. Therefore, contradiction between making a monetary policy ensuring macroeconomic targets and managing the banking system is inevitable. To help the SBV operate effectively, we suggest separating those two functions and giving the SBV more autonomy and independence from the government.

\section{CONCLUSIONS}

Based on the theoretical model, this research presents three predictions of reactions by banks in response to changes in the policy rate under capital and liquidity constraint requirements. Empirical evidences gathered from Vietnam commercial banks during the period 2009-2012 show that (i) the loan rates of capital constrained banks are higher than those of unconstrained banks; (ii) the pass-through from the policy rates to loan rates is not obvious in both constrained and unconstrained banks; and (iii) the loan rates of capital constrained banks are more sensitive to changes in the aggregate demand.

This paper, however, has several limitations in data accession such as the small number of observations in both space and time, incompletely reported financial statements and inadequacies in management of interest rate that makes the refinancing rate less effective.

The reason for this problem is that banking regulations with their microprudential rather than macroprudential characteristics induce the loan rate asymmetry. Hanson et al. (2010) distinguished two approaches to management of financial system: microprudential approach and macroprudential approach. The goal of the former is to 
prevent the losses of individual financial organizations. On the other hand, macroprudential approach takes a more comprehensive view than the microprudential one's, and aims at ensuring safety for the whole financial system. Thus, in our opinion, the cause of the ineffective policy is the microprudential approach adopted by financial authorities. We therefore would like to suggest that government should manage the financial system by the macroprudential approach instead of the microprudential one to ensure a comprehensive development and stability for Vietnam's financial system

\section{Note}

[1] The SBV manages the interest rate via three types of interest rates: base rate, rediscount rate and refinancing rate. However, base rate almost remains unchanged or only changes slightly; thus it is not suitable for the research. Additionally, rediscount rate changes at the same level as refinancing rate; therefore, refinancing rate is used as a representative for the variable "policy interest rate in Vietnam".

\section{References}

Allen, F., E. Carletti \& D. Gale (2009), "Interbank Market Liquidity and Central Bank Intervention," Journal of Monetary Economics 56, pp. 639-652

Basel Committee on Banking Supervision (2011), "Basel III: A Global Regulatory Framework for More Resilient Banks and Banking Systems," Bank of International Settlements

Berger, A.N. \& C.H.S. Bouwman (2011), "How Does Capital Affect Bank Performance During Financial Crises?” Financial Institutions Center, Working Paper \#11-36.

Bernanke, B. S. \& M. Gertler (1995), "Inside the Black Box: The Credit Channel of Monetary Policy Pass-through," The Journal of Economic Perspectives, 9(4), pp. 27-48.

Camen, U. (2006), “Monetary Policy in Vietnam: The Case of a Transition Country”, BIS Papers No. 31.

Cornett, M.M., J. J. McNutt, P.E. Strahan \& H. Tehranian (2011), "Liquidity Risk Management and Credit Supply in the Financial Crisis,” Journal of Financial Economics 101, pp. 297-312.

Fuertes, A.-M. \& S.A. Heffernan (2006), "Bank Heterogeneities in the Interest Rate Pass-through Mechanism," Economic \& Social Research Council.

Hannan, T.H. \& A.N. Berger (1991), "The Rigidity of Prices: Evidence from the Banking Industry," The American Economic Review 81(4), pp. 938-945.

Hanson, S.G., A. K. Kashyap \& J.C. Stein (2010), “A Macroprudential Approach to Financial Regulation,” Chicago Booth Research Paper 10-29. 
Kumhof, M., D. Laxton, D. Muir \& S. Mursula (2010), “The Global Integrated Monetary and Fiscal Model (GIMF) - Theoretical Structure," International Monetary Fund Working Paper 10/34.

Le Viet Hung \& W. Pfau (2008), "VAR Analysis of the Monetary Pass-through Mechanism in Vietnam", Applied Econometrics and International Development, Vol. 9, No. 1, pp. 165-179.

Lim, G.C. (2001), “Bank Interest Rate Adjustments: Are They Asymmetric?” The Economic Record, 77(237), pp. 135-147.

Ming-Hua L., D. Margaritis, A. Tourani-Rad (2008), "Monetary Policy Transparency and Passthrough of Retail Interest Rates", Journal of Banking \& Finance (32), 4/2008, pp 501-511.

Mishkin, F. (1996), “The Channels of Monetary Pass-Through: Lessons for Monetary Policy”, NBER working paper series.

Mishkin, F. (2009), “Is Monetary Policy Effective During Financial Crises?” NBER Working Paper 14678.

Nguyễn Ngọc Bảo, 2011, "Một số vấn đề về cơ chế điều hành lãi suất hiện nay của Ngân hàng Nhà nước đối với ổn định thị trường tiền tệ", retrieved from http://www.vnba.org.vn on July 16, 2013.

Nguyễn Phi Lân (2012), “Cơ chế truyền dẫn tiền tệ dưới góc độ phân tích định lượng”, retrieved from http://www.sbv.gov.vn on March 15, 2013.

Nguyễn Thị Kim Thanh, 2011. “Chính sách lãi suất: Cơ sở lý luận và thực tiễn”, retrieved from http://www.vnbaorg.info on July 16, 2013.

Roelands, S. (2012), “Asymmetric Interest Rate Pass-Through from Monetary Policy: The Role of Bank Regulation”, Bowling Green State University; University of Notre Dame.

Saunders, A. \& L. Schumacher (2000), "The Determinants of Bank Interest RateMargins: An International Study," Journal of International Money and Finance 19, pp. 813-832.

SBV (2010), Circular 13/2010/TT-NHNN (Thông tư quy định về các tỷ lệ bảo đảm an toàn trong hoạt động của tổ chức tín dụng).

Taylor, J. B. (1993), "Discretion versus Policy Rules in Practice", Carnegie-Rochester Conference Series on Public Policy 39: 195-214. 